Received 17 June 2021

Accepted 13 August 2021

Link to DOI:

10.25220/WNJ.V04.i2.0011

Journal Website:

www.worldnutrijournal.org

\section{The role of nutrition and pancreatic enzyme replacement therapy in children with cystic fibrosis}

\author{
Muzal Kadim${ }^{1}$, William Cheng ${ }^{2}$ \\ 1. Division of gastrohepatology, Child Health Department, Faculty of Medicine, Universitas \\ Indonesia-Cipto Mangunkusumo Hospital, Jakarta, Indonesia \\ 2. Child Health Department, Faculty of Medicine, Universitas Indonesia-Cipto Mangunkusumo \\ Hospital, Jakarta, Indonesia
}

\begin{abstract}
Background Cystic fibrosis (CF) is an inherited genetic disorder with high mortality and morbidity. CF is strongly correlated with malnutrition due to higher energy losses, pancreatic insufficiency, chronic inflammation, higher resting energy expenditure, and feeding problems. Malnutrition in CF patients associated with worse survival. Thus, appropriate and prompt nutritional intervention should be addressed to reduced malnutrition in CF patients.

Methods The literature search was performed on 9 August 2021 in four major databases such as MEDLINE, EBSCOhost, Cochrane Reviews, and Web of Sciences to find the role of nutrition and pancreatic enzyme replacement therapy in pediatrics population with cystic fibrosis.

Recent findings In recent decades, early nutritional management and pancreatic enzyme replacement therapy (PERT) have been shown to improve CF patient's outcomes. Nutrition should be given in higher calories compared to healthy individuals with close and regular nutritional status monitoring. High protein and fat diets are essential for CF patient's overall survival. Adequate level of micronutrients should be ensured to avoid morbidity caused by micronutrients deficiency. Regular pancreatic insufficiency screening should be done annually in order to start PERT early. Further research focusing on body composition, growth chart, protein intake, and PERT are needed to further improve the management of CF patient.

Conclusion Nutritional intervention and PERT play an important role in prolonging CF patient survival. Both treatments should be initiated early with nutritional status close monitoring and tailored to each individual. Collaboration with parents and children is critical to warrant that CF patients followed the dietary advice.

Keywords cystic fibrosis, nutritional therapy, pancreatic enzyme therapy
\end{abstract}




\section{Introduction}

Cystic fibrosis (CF), also known as mucoviscidosis, is one of the most common lethal inherited autosomal recessive genetic disorders found in the Caucasian population. There are approximately 1 in every 3,000 - 4,000 Caucasians born with this disorder. Although $\mathrm{CF}$ is notably found in Caucasians, it could also occur in other ethnicities with lesser prevalence. ${ }^{1}$

Cystic fibrosis is caused by mutation in gene encoding the Cystic Fibrosis Transmembrane Conductance Regulator (CFTR) protein. Mutation leading to CFTR dysfunction mainly in regulating sodium and chloride transport system across numerous epithelial and other membrane cells. There are over one thousands of CFTR mutations of which give rise to its broad spectrum of phenotypes, ranging from single-organ pathology to classic $\mathrm{CF}{ }^{2}{ }^{2}$ $\mathrm{CF}$ can affect multiple organs such as liver, reproductive organs, intestine, and others, with considerable morbidity and mortality especially comes from its pathology in lungs and pancreas. ${ }^{1}$

In the lungs, the chloride ion channel dysfunction results in decreased airway surface liquid, causing dehydration, thickened mucus, and ciliary function impairment. This condition promotes microorganisms to infect and causing inflammation, hence damaging and obstruct the airway. This vicious cycle of infection, inflammation, and airway obstruction contributes to the significant mortality in CF patients. In pancreas, the mechanism of chloride absorption and bicarbonate secretion of pancreatic ductal epithelial cells play essential roles in fluid secretion and optimizing digestive enzyme's function. The CFTR mutation found in CF patients altered those mechanisms, causing pancreatic secretions to become lower in volume and $\mathrm{pH}$ with higher protein content, thus obstructing intrapancreatic ducts and impairing the absorption process. This premise is further supported by the fact that around $15-20 \%$ of CF babies have meconium ileus shortly after born. Malabsorption leading to undernutrition also expected due to the exocrine pancreas and intestinal resorptive processes malfunction, generating other morbidities for $\mathrm{CF}$ patients. $^{3}$
Numerous CF complications caused a lot of children did not surpass the first five years of life, with life expectancy approximately only six months when CF first introduced in 1938. Decades later, after the researcher's continuous effort to advance and develop CF therapies, there is a significant improvement in CF patients' survival with median survival age now beyond 30 years. One of the main pillar among other CF key treatment that could markedly increase patient's survival is nutritional management. ${ }^{4}$

Nutrition plays a vital role in $\mathrm{CF}$ prognosis; however, patient with $\mathrm{CF}$ usually presented with some degree of undernutrition due to malabsorption secondary to pancreatic insufficiency, higher energy intake, higher energy losses, and abnormal metabolic activity. Malnutrition in CF patients has been found to strongly correlated with poor pulmonary outcome, meanwhile good nutritional status is associated with prolonged survival and better lung function. Thus, close monitoring of nutritional status and early nutritional management is critical for CF patient's overall survival. This review aims to summarize the latest evidence and guideline regarding the role of nutritional intervention along with the use of pancreatic enzyme replacement therapy in CF management, especially in the pediatric population.

\section{Methods}

In order to summarize the role of nutritional intervention and pancreatic enzymes in $\mathrm{CF}$, a database search has been performed using MEDLINE, EBSCOhost, Cochrane Reviews, and Web of Sciences on 9 August 2021. The search strategy was conducted by using keywords such as "pediatric", "infant", "children", "nutrition therapy", "diet therapy", "pancreatic enzyme replacement therapy", "PERT", "cystic fibrosis", and "mucoviscidosis". The inclusion criteria were English language journal articles, guidelines, review articles, systematic review, or meta-analysis with pediatric as a subject population. The exclusion criteria were literatures that have been published for more than 5 years. Exceptional will be made for aged articles providing information that could not be found in recent articles. 


\section{Results and Discussion}

\section{Nutritional status and cystic fibrosis}

Cystic fibrosis patients often presented with malnutrition. European Cystic Fibrosis Society (ECFS) Patient Registry data showed that in 2010 about half of $\mathrm{CF}$ patients have some degree of malnutrition. The latest ECFS Patient Registry data showed that after the age of 2 , children with CF have a lower average BMI compared with their non-CF same-age population. ${ }^{5}$ Several underlying mechanisms for malnutrition such as increased resting energy expenditure (REE), malabsorption caused by pancreatic insufficiency, deficiency of fat-soluble vitamins, chronic inflammation, $\mathrm{CF}$ related diabetes, decreased appetite (due to medications side effects), gastrointestinal problems (constipation, bacterial overgrowth, distal intestinal obstructive syndrome), and behavioral feeding problems. Malnutrition in CF leads to worse outcomes on account of worse lung function, immunological alteration, lower quality of life, stunted growth, and shorten life expectancy. ${ }^{6}$ The risk of malnutrition further worsen by CF-related diabetes and other metabolic complications. In CFrelated diabetes, patients have insulin deficiency that will lower insulin's anabolic activity. Other CF complication, CF-related liver disease, correlated with several nutritional deficiencies, especially calcium, essential fatty acids, and fat-soluble vitamins. $^{7}$

For decades, effort has been made to decrease malnutrition in CF patients by using diet high in calorie and fat, fat-soluble vitamin supplementation, and pancreatic enzyme replacement therapy (PERT). Those efforts resulted in the improvement of CF patient's nutritional status. The median BMI percentiles of children with CF in 2002 is $43 \%$ meanwhile, in 2017 the median increased to $75.1 \%$. The same improvement could also be seen in the number of children with a weight $<10^{\text {th }}$ of which the number decreased from $23.1 \%$ to $10.4 \%{ }^{8}$

The role of nutritional management in cystic fibrosis patient

Nutritional intervention should be started as early as possible by the time cystic fibrosis diagnosis is made, with the best outcome came from the detection in the first days of life through newborn screening. ${ }^{9}$ A good nutritional status is strongly associated with a better outcome, lower incidence of CF-related diabetes, fewer days of hospitalization, and better lung function. Better lung function has been proved by the capability of Forced Expiratory Volume in one second (FEV1) to reach its highest potential at six years of age in those children who reached the $50^{\text {th }}$ percentile of weight for length/BMI earlier in life. After reached the higher FEV1, child with CF have been seen able to maintain good growth pattern for the rest of their early childhood. ${ }^{10}$

Given the importance of nutritional status, nutritional care should be started aggressively early in life, preferably in the first year of life and continued over the lifetime. The European Society for Clinical Nutrition and Metabolism-The European Society for Pediatric Gastroenterology Hepatology-and The European Cystic Fibrosis Society (ESPEN-ESPGHAN-ECFS) through their guideline recommends that $\mathrm{CF}$ patients nutritional status should be monitored frequently by measuring anthropometric status (weight, height, BMI) and body composition. ${ }^{11}$ Body composition should also be measured due to the fact that around 14\%-24\% CF child with normal BMI has low fat-free mass (including muscle). Muscle composition correlated with better prognosis. Children with normal BMI do not necessarily have a better outcome if they have a low lean mass of muscle. One of the methods used in measuring body composition is using BioElectrical Impedance Analysis (BIA) with CFspecific equations, one of which was developed by Charatsi et al. BIA with CF-specific equations showed better accuracy in reflecting overall nutritional status than other examinations without validation to $\mathrm{CF} .{ }^{12}$ However, there is also other recommended body composition assessment such as dual-energy X-ray absorptiometry (DXA), air displacement plethysmography, handgrip strength, and double-labeled water measurement. There was still limitation in the usage of body composition such as the unavailability of consensus on the used equation, technique, and proper references. Hence, there was no consensus in the threshold for fat free mass and fat free mass index, warranting further studies. ${ }^{13}$

Besides muscle mass, bone mineral density (BMD) should also be assessed. Lean body mass and 
bone mineral content are shown to better reveal nutritional deficits rather than low BMI and better predict lung function. Calella et al. found that lean body mass has significant correlation with $\mathrm{FEV}_{1}$ and was a significant predictor for pulmonary function. ${ }^{14}$ Lower values of fat free mass and bone mineral density are associated with worse lung function. BMD is evaluated by using DXA due to high rate of osteopenia and osteoporosis in CF patients. The European Cystic Fibrosis Bone Mineralization Guidelines recommend that DXA examination be performed every 1-5 years, starting from 8 to 10 years of age. For children with short height (the height is $>$ one standard deviation lower than sameage healthy children), bone mineral density $\mathrm{Z}$ score should be adjusted for their statural age to avoid overestimation in children with short stature. ${ }^{11}$

The frequency of nutritional status measurement depends on the patient's age and their nutritional status at the time of their presentation. Infants (0-2 years old) with undernutrition should undergo nutritional status measurement every 1-2 weeks until they reached the $0 \mathrm{SD}\left(50^{\text {th }}\right.$ percentile $)$ weight and length for healthy same-age population. After they reached the intended nutritional status, they could continue monitoring monthly for their first year of life and every three months after. Ideally, every malnourished or stunted children should be monitored more frequently. ${ }^{11}$

To ensure the success of nutritional intervention program, parents should be educated with this higher daily intake needs so they could provide the CF child with appropriate and balanced diets. Dietary counseling should also be given to the child to maintain healthy feeding and correct behavioral feeding problems commonly found in CF patient. A dietary review using 24-h recall or 3-5 days diet record will help in the qualitative and quantitative evaluation of nutritional intake. Thus, dietary review is recommended to be performed every 3 months especially for those with nutritional risk. ${ }^{11}$

Special consideration should be taken in CFrelated diabetes (CFRD). CF patients with diabetes tend to have lower BMIs and height compared to those without diabetes. The nutritional decline commonly started 4 years before CFR diagnosis and was believed to be resulted from the catabolic effects of insulin insufficiency. In CFRD, good nutritional status should be achieved while maintaining the normal blood glucose levels. In general, patients with CFRD followed the same dietary recommendations with those without diabetes. However, there are several adjustments. In carbohydrate consumption, refined simple sugar particularly sugary beverages, juices and soda pop should be restricted. It is recommended to consume six servings of grains and 3-4 servings of dairy daily. In fats consumption, it is recommended to have food with higher omega-3 fatty acids content to lower inflammation which commonly seen in CFRD. ${ }^{16}$

For newly diagnosed infants, the energy intake should come from exclusive breastfeeding if possible. If exclusive breastfeeding is not possible, regular infant formula can be used. Evidence showed that breastfed infants had better lung functions and fewer infections, possibly because of better immune function and docosahexaenoic acid (DHA) content in breastmilk. Children with poor growth or malabsorption might get benefit from high energy or hydrolyzed formula. However, there are no enough evidence to support the usage of those formulas. Both breastfed or formula-fed infants should take additional sodium supplementation and be introduced to solid food at the same time with healthy infants. ${ }^{11}$ The summary of energy and macronutrient recommendation can be seen in Table 1.

\section{Recommendation for micronutrient intake}

CF patients often have micronutrient imbalance due to intestinal malabsorption, chronic inflammation, and increased sweating. Extra attention especially should be put on salt, iron, calcium, and zinc content. Salt supplementation is needed in all CF patients. Breastmilk, standard formula, and baby foods have relatively low sodium content and do not provide adequate sodium. Sodium deficiency could impair infant growth; thus, sodium assessment and supplementation should be carried out in infants. The ESPEN-ESPGHAN-ECFS guideline recommends that breastfed infants are given 1-2 $\mathrm{mmol} / \mathrm{kgbodyweight} /$ day sodium diluted in formula or water whenever sodium deficiency is discovered. However, this dosage can be increased by considering the presence of hot environmental conditions, diarrhea, vomiting, or other conditions that could make significant sodium losses. The 
North American guidelines recommend that sodium supplementation in infants does not exceed 4 $\mathrm{mmol} / \mathrm{kg}$ body weight/day. In older children, the body's sodium level could be assessed through sodium: creatinine ratio. Supplementation could be given by sodium chloride capsules administered several times a day. ${ }^{11}$

Malabsorption in CF patients leads to low level of fat-soluble vitamins, including vitamin D. Low level of vitamin D resulted in low calcium. Calcium level in CF patients should be assessed at least annually with special consideration in children with growth faltering or weight stagnation. Calcium supplementation should be given if calcium intake is deficient, according to the daily recommended calcium intake established by the European Food Safety Authority (EFSA) that is shown in the summary table below (Table 2). ${ }^{11}$

Malabsorption also leads to iron deficiency in $\mathrm{CF}$ patients, resulted in iron deficiency anemia and poor outcome. Iron levels should be monitored annually. The ESPEN-ESPGHAN-ECFS guidelines recommend that iron deficiency be screened first through serum iron values. If the result is low, further laboratory work such as serum ferritin, transferrin saturation, and total iron-binding capacity should be done to differentiate between iron deficiency anemia or anemia of chronic inflammation. Iron supplementation could be given if the iron deficiency is proved. ${ }^{11}$

Zinc deficiency was correlated with growth faltering, eye problems, delayed sexual maturation, and anorexia in CF patients. Thus, zinc supplementation is recommended in CF child with aforementioned condition with the supplementation dosage $1 \mathrm{mg} / \mathrm{kg} /$ day ( $\max 15 \mathrm{mg} /$ day) in infants $(0-$ 2 years) and $15 \mathrm{mg}$ /day in older children (2-18 years). The supplementation is suggested to be given in 6 months.

CF children are commonly found with fat-soluble vitamin (vitamin $A, D, E, K$ ) deficiency with a prevalence $10-35 \%$, resulted from pancreatic insufficiency. Low levels of vitamin A correlated with impaired lung function and poorer clinical status in CF patient. Low levels of vitamin D associated with reduced bone mineral density. Low levels of vitamin $E$ resulted in the increase of oxidative damage and low level of vitamin $\mathrm{K}$ leads to increase susceptibility of significant bleeding and low bone mineral density. Numerous morbidities associated with fat-soluble vitamin give a rationale for fat-soluble vitamin plasma level evaluation annually. If there is a deficiency, supplementation should be given. It is better to consume the vitamins simultaneously with high-fat diets and pancreatic enzyme supplementation to increase absorption. ${ }^{11}$

Vitamin A level in serum should reach the normal range of serum retinol concentration. Supplementation can be started by giving low-dose retinol and gradually stepping up the dosage guided by the evaluation of serum values. Alternatively, in children age 6-8 years, supplementation can also be given in the form of daily provitamin beta carotene, with the dosage $1 \mathrm{mg} / \mathrm{kg}$ body weight/ day for 2 weeks and with $10 \mathrm{mg}$ /day as maintenance dose thereafter. If the normal values have been achieved, the frequency of retinol serum level concentration could be lowered to once in a year. The sign of vitamin A toxicity should also be evaluated regularly. ${ }^{17}$

For vitamin $\mathrm{D}$, there is a variety of recommended plasma levels between studies. The US Cystic Fibrosis Foundation recommends the minimal threshold for 25-hydroxy vitamin D (25(OH)D) concentration in serum is $30 \mathrm{ng} / \mathrm{mL}$, meanwhile The European Cystic Fibrosis Bone Mineralization and the ESPEN-ESPGHAN-ECFS guidelines recommends the minimum value is $20 \mathrm{ng} / \mathrm{mL}$. The supplemental dose of vitamin D is still being debated; however, it is recommended to give 400 IU/day with maximum dose $1000 \mathrm{IU} /$ day in infants, and 800 IU.day with maximum dose 2000 IU and $4000 \mathrm{IU} /$ day for children 1-10 years and $>10$ years, respectively. Vitamin D dosage should also be determined based on the initial serum concentration, sun exposure degree, and dietary intake. Similarly with vitamin A, vitamin D serum levels should also be monitored annually. ${ }^{11}$

Regular vitamin E ( $\alpha$-tocopherol) supplementation in $\mathrm{CF}$ patients is also recommended especially for patient with serum $\alpha$ tocopherol:cholesterol ratio less than $5.4 \mathrm{mg} / \mathrm{g}$. The vitamin $\mathrm{E}$ supplement should be given in order to achieve the recommended serum $\alpha$-tocopherol concentration for CF patient. Lastly, another fatsoluble vitamin that should be given to CF patient is Vitamin $\mathrm{K}_{1}$. Until now, there is no consensus in the most effective dosing for vitamin $\mathrm{K}_{1}$. However, it is 
believed that the best supplementation dosage are $0.3-1 \mathrm{mg} / \mathrm{day}$ for infants and $1-10 \mathrm{mg} / \mathrm{day}$ for older children and adults. ${ }^{11}$

\section{The goal for nutritional status}

The main goal for CF patient is to reach the same growth with their healthy same-age population when at the same time also have a high lean body (muscle) mass. Indicators that are used for defining adequate nutritional status differs from age to age. In infants (0-2 years), the nutritional status is said to be sufficient when patient weight for length (WFL) reached $\geq 50^{\text {th }}$ percentile of their age-matched healthy population. Meanwhile in older children (218 years), the indicator is $\geq 50^{\text {th }}$ percentile of BMI. Ideally, growth chart adapted from patient own ethnicity or nationality will be better to evaluate the nutritional status. If there are no adapted growth chart version, international growth chart (GC) 2006 by World Health Organization (WHO) and Centers for Disease Control and Prevention (CDC) 2000. Originally, WHO $2006 \mathrm{GC}$ is commonly used in infant aged 0-2 years meanwhile CDC 2000 in older children aged 2-18 years. However, in the CF population, there were discrepancy between those two GCs in certain ages. Zhang et al. reported that $29 \%$ children aged 2 years with WFL $\geq 50^{\text {th }}$ percentile on WHO GC were $<50^{\text {th }}$ percentile on CDC GC. Besides, in BMI GC, $50^{\text {th }}$ percentile on CDC GC was equal with $70^{\text {th }}$ percentile and $67^{\text {th }}$ percentile on WHO GC. This discrepancy resulted on inaccurate nutritional target and clinical outcomes prediction. Machogu et al. in his study found that patients with WFL $\geq 50^{\text {th }}$ percentile on both charts had a significant higher $\mathrm{FEV}_{1}$ compared to $W F L \geq 50^{\text {th }}$ percentile on single chart alone. This finding resulted in the release of Cystic Fibrosis Foundation guideline with WFL target $\geq 75^{\text {th }}$ percentile on WHO GC for children aged 12-24 months. Further studies comparing long term outcomes in $\mathrm{CF}$ patients using $\mathrm{WHO}, \mathrm{CDC}$, or national $\mathrm{GC}$ are needed. ${ }^{13}$

CF children that already reached their desired nutritional status can be given preventive nutritional counseling in order to maintain their good nutrition. If the children experienced weight stagnation, weight faltering, or failure to thrive, diet modification and oral nutritional supplementation should be given to promote adequate growth. For children with persistent undernutrition, another measure such as enteral tube feeding, should be considered.

Anthropometric measurement using BMI alone in older children is not enough to define adequate nutritional status. Body composition measurement should also be done to ensure that lean body (muscle) mass contributed for a significant portion in those measurement. High BMI with low lean body mass and high fat composition in the exact opposite, contributed for poor outcome. ${ }^{15}$ Additionally, annual blood tests for nutritional review; such as iron status, blood count, electrolyte, plasma fat-soluble vitamin levels, serum liver function test; should also be performed to further evaluate CF patient nutritional status. ${ }^{11}$ Table 3 summarizes the goal of nutritional status in $\mathrm{CF}$ patients.

The role of pancreatic enzyme replacement therapy in cystic fibrosis patient

Pancreatic insufficiency is found in $85-90 \%$ of $\mathrm{CF}$ patients and strongly correlated with malnutrition. It is commonly developed in the first year of life. The CFTR mutation impaired the chloride and bicarbonate transport system in pancreatic epithelial causing pancreatic secretions became thickened with decreased $\mathrm{pH}$, leading to pancreatic ductal obstruction. Pancreatic chronic obstruction resulted in the impairment of pancreatic exocrine enzyme digestive function and created fibrosis leading to pancreatic insufficiency. CF patient with pancreatic insufficiency could not digest and absorb fat diet or fat-soluble vitamin due to the dysfunction of exocrine pancreatic enzyme, hence, the infants with pancreatic insufficiency commonly have lower weight and length z-score compared to their healthy counterparts. The children passed $80 \%$ of their diet fat contents in their stool due to lipase deficiency. ${ }^{18}$ The pancreatic insufficiency should always be screened in every $\mathrm{CF}$ patient by the time of diagnosis and should be repeated annually. CF patient should also be questioned about gastrointestinal symptoms during clinical follow-up. Pancreatic insufficiency ought to be suspected if patient clinically has diarrhea without any other possibility or known to have 2 CFTR mutation that associated with pancreatic insufficiency. ${ }^{11}$ Several methods to 
diagnose pancreatic insufficiency such as fecal pancreatic elastase-1 examination and coefficient of fat absorption. If the results are abnormal, the PERT should be initiated as early as possible. The abnormal results defined by low fecal pancreatic elastase-1 $(<100 \mu \mathrm{g} / \mathrm{g}$ stool $) .{ }^{18}$

Nowadays, PERT has becoming one of the main treatment for $\mathrm{CF}$ patients due to its ability in improving life expectancy and nutritional status of CF patients (Table 4). ${ }^{19}$ ECFS Registry Data collected from 38 countries showed that in 2018, approximately $83 \%$ patient with CF has already used PERT. ${ }^{5}$ The dosage for PERT determined by the lipid content in patient diet and the lipase needed for the diet. For infants up to 12 months, it is recommended to give $2000-4000 \mathrm{U}$ lipase $/ 120 \mathrm{~mL}$ breastmilk or formula and $2000 \mathrm{U}$ lipase/gram of fat in diet if infants already consume solids. For children 1-4 years, it is recommended to take 2000$4000 \mathrm{U}$ lipase/gram dietary fat with maximum dosage 10.000/U lipase/kg per day. In children $>4$ years, it is suggested to take PERT with starting dose $500 \mathrm{U}$ lipase $/ \mathrm{kg} / \mathrm{meal}$ with maximal dosage 10.000 $\mathrm{U} /$ lipase/kg per day. PERT usually given in the form of enteric-coated tablets or microsphere. ${ }^{11}$ However the dosing of PERT was still much debated. The usage of lipase units/kg body weight/meal as a denominator only used body weight to decide PERT dosage and could result in over or under supplementation based on the nutrient intake. Meanwhile, the usage of lipase units/g fat does not implicate other macronutrients. ${ }^{13}$ Besides, there was no correlation found between PERT dose and BMI. Gelfond et al in his studies found that the higher PERT dosing do not give a better clinical benefit compared to lower dosing regimen. ${ }^{20}$

\section{Other important assessment in cystic fibrosis children}

CF correlated with numerous complications. Other examinations are performed in order to detect those complications in early stage. The measurement of pulmonary function by using forced expiratory volume in $1 \mathrm{~s}\left(\mathrm{FEV}_{1}\right)$ should be performed every 3 months to detect the decline of lung function. FEV 1 can also be used to evaluate the improvement after nutritional intervention. $\mathrm{CF}$ also could lead to liver disease; thus, the liver function should also be monitored annually by physical examination, enzyme assays, and ultrasound. Liver disease should be suspected if CF patient presented with hepatomegaly, persistent abnormal liver function test (3 months consecutive above upper normal limits aspartate transaminase, alanine transaminase, and gamma-glutamyl transpeptidase), and abnormal ultrasonography. The blood glucose test is suggested to be conducted annually in order to detect CFrelated diabetes. ${ }^{11}$

\section{Conclusion}

Nutritional intervention and PERT play an essential role in $\mathrm{CF}$ management and contribute to better survival. Given its importance, nutritional intervention and PERT should be initiated as early as possible by the time the CF diagnosis is made. The nutritional intervention consists of giving a higher daily energy intake than healthy individuals (with special consideration to higher protein and fat diet composition), micronutrient supplementation, and fat-soluble vitamins supplementation. The nutritional status should be monitored regularly by measuring the anthropometric status. In addition, other assessments that could also reflect nutritional status should also be performed regularly, such as body composition, bone mineral density, numerous serum biomarkers, and electrolyte concentration. Collaboration with parents and children also important. Parents and children should be educated on the importance of following dietary nutrition advice and regularly checking their condition. Besides nutritional intervention, PERT should be initiated early when pancreatic insufficiency is suspected in follow-up visit. Early administration of PERT correlated with better outcomes.

Even though a comprehensive guideline in managing CF patient nutrition was already available, there are some potential fields to be explored in order to further improving holistic $\mathrm{CF}$ management. Research aims to determine the consensus in body composition measurement (in regard to its technique, equation, fat free mass and fat free mass index threshold) and growth chart; further investigation in recommended protein intake and protein sources that could easily digested by $\mathrm{CF}$ patient; and accurate PERT intakes, are needed. 
Table 1. The summary of energy and macronutrient recommendation in CF patient ${ }^{11,16}$

\begin{tabular}{|c|c|c|}
\hline Topic & Age & Recommendation \\
\hline $\begin{array}{l}\text { Recommended Daily } \\
\text { Energy Intake }\end{array}$ & All ages & $\begin{array}{l}110-200 \% \text { calories of their recommended dietary allowance for similar- } \\
\text { age healthy population }\end{array}$ \\
\hline Dietary Composition & All ages & $35 \%-40 \%$ fat, $40-45 \%$ from carbohydrates, and $20 \%$ protein \\
\hline \multirow[t]{2}{*}{ Education } & $\begin{array}{l}\text { Infants and } \\
\text { younger child }\end{array}$ & $\begin{array}{l}\text { Parents should be educated about child's higher daily energy intake needs } \\
\text { so they could provide the CF child with appropriate and balanced } \\
\text { composition of diets }\end{array}$ \\
\hline & Older child & $\begin{array}{l}\text { Dietary counseling should be given to maintain healthy feeding and } \\
\text { correct behavioral feeding problems }\end{array}$ \\
\hline Dietary Review & All ages & $\begin{array}{l}\text { Dietary review should be assessed every } 3 \text { months by using } 24-\mathrm{h} \text { recall or } \\
3-5 \text { day diet record in order to evaluate qualitative and quantitative } \\
\text { nutritional intake and whether patient/parents have already adhered to } \\
\text { nutritional advices. }\end{array}$ \\
\hline CFRD & All ages & $\begin{array}{l}\text { Carbohydrate: limit refined simple sugar, six servings of grains, and 3-4 } \\
\text { servings of dairy } \\
\text { Fats: consume food with higher omega-3 fatty acids content }\end{array}$ \\
\hline Breastfeeding & $\begin{array}{l}\text { Infants }(0-2 \\
\text { years })\end{array}$ & $\begin{array}{l}\text { Exclusive feeding if possible, formula feeding if not possible, with } \\
\text { additional sodium supplementation. Solid foods should be started at the } \\
\text { same age with healthy population. }\end{array}$ \\
\hline
\end{tabular}

Table 2. The summary of micronutrient recommendation in CF patient ${ }^{11}$

\begin{tabular}{|c|c|c|c|}
\hline Micronutrient & Age & Evaluation & Recommendation \\
\hline \multirow[t]{2}{*}{ Sodium } & Infants $(0-2$ years $)$ & \multirow[t]{2}{*}{$\begin{array}{l}\text { Sodium:creatinine } \\
\text { ratio }\end{array}$} & $\begin{array}{l}1-2 \mathrm{mmol} / \mathrm{kg} \text { body weight/day sodium diluted in } \\
\text { formula or water. Can be increased up to } 4 \\
\mathrm{mmol} / \mathrm{kg} \text { body weight/day (in the present of hot } \\
\text { environmental conditions, diarrhea, vomiting) }\end{array}$ \\
\hline & Older children & & $\begin{array}{l}\text { Sodium chloride capsules administered several } \\
\text { times a day }\end{array}$ \\
\hline \multirow[t]{6}{*}{ Calcium } & 0-6 months & \multirow{6}{*}{$\begin{array}{l}\text { Calcium intake should } \\
\text { be assessed annually. } \\
\text { More frequent } \\
\text { assessment can be } \\
\text { performed if there is a } \\
\text { growth faltering }\end{array}$} & $200 \mathrm{mg}$ daily \\
\hline & 7-11 months & & $280 \mathrm{mg}$ daily \\
\hline & $1-3$ years & & $450 \mathrm{mg}$ daily \\
\hline & $4-10$ years & & $800 \mathrm{mg}$ daily \\
\hline & 11-17 years & & $1150 \mathrm{mg}$ daily \\
\hline & $18-25$ years & & $1000 \mathrm{mg}$ daily \\
\hline Iron & All ages & $\begin{array}{l}\text { Annually using serum } \\
\text { iron. If the SI is } \\
\text { abnormal, performed } \\
\text { serum ferritin, } \\
\text { transferrin saturation, } \\
\text { and total iron binding } \\
\text { capacity test. }\end{array}$ & $\begin{array}{l}\text { Give iron supplementation only after resolving } \\
\text { other possible etiology (example: inflammation) } \\
\text { and the iron deficiency still persists }\end{array}$ \\
\hline \multirow[t]{2}{*}{ Zinc } & $\begin{array}{l}\text { Infants }(0-2 \text { years }) \\
\text { with zinc deficiency } \\
\text { risk }\end{array}$ & \multirow{2}{*}{$\begin{array}{l}\text { Identify infants or } \\
\text { child with zinc } \\
\text { deficiency risk: growth } \\
\text { faltering, eye } \\
\text { problems, delayed } \\
\text { sexual maturation, and } \\
\text { anorexia }\end{array}$} & $1 \mathrm{mg} / \mathrm{kg} /$ day (maximum $15 \mathrm{mg} /$ day) for 6 months \\
\hline & $\begin{array}{l}\text { Child }>2 \text { years with } \\
\text { zinc deficiency risk }\end{array}$ & & $15 \mathrm{mg} /$ day for 6 months \\
\hline \multicolumn{4}{|c|}{ Fat-Soluble Vitamins } \\
\hline Vitamin A & All ages & $\begin{array}{l}\text { Annually, and 3-6 } \\
\text { months after the } \\
\text { change in dosage. }\end{array}$ & $\begin{array}{l}\text { Vitamin A supplementation should be given if } \\
\text { patient do not reach their normal range of serum } \\
\text { retinol concentration. The supplementation that } \\
\text { could be given: }\end{array}$ \\
\hline
\end{tabular}




\begin{tabular}{|c|c|c|c|}
\hline & & $\begin{array}{l}\text { Evaluate sign of } \\
\text { toxicity }\end{array}$ & $\begin{array}{l}\text { - Retinol (low-dose, gradually increase the } \\
\text { dosage guided by the retinol serum values) }\end{array}$ \\
\hline & children age 6-8 years & & $\begin{array}{l}\text { Alternative to retinol, daily provitamin beta } \\
\text { carotene } 1 \mathrm{mg} / \mathrm{kg} \text { body weight/ day for } 2 \text { weeks and } \\
10 \mathrm{mg} / \text { day as maintenance dose thereafter }\end{array}$ \\
\hline \multirow[t]{3}{*}{ Vitamin D } & Infants & \multirow{3}{*}{$\begin{array}{l}\text { Annually, and 3-6 } \\
\text { months after the } \\
\text { change in dosage. The } \\
\text { minimum target is } \\
\text { serum-25 (OH) D } \\
\text { 20ngmL }\end{array}$} & $400 \mathrm{IU} /$ day (maximum $1000 \mathrm{IU} /$ day) \\
\hline & Children $1-10$ years & & 800 IU/day (maximum 2000 IU/day) \\
\hline & Children $>$ 10years & & 800 IU/day (maximum 4000 IU/day) \\
\hline Vitamin E & $\begin{array}{l}\text { Infants }(<12 \text { months }) \\
>1 \text { years }\end{array}$ & $\begin{array}{l}\text { Annually, and 3-6 } \\
\text { months after the } \\
\text { change in dosage. The } \\
\text { target is serum } \alpha- \\
\text { tocopherol :cholesterol } \\
\text { ratio }>5.4 \mathrm{mg} / \mathrm{g}\end{array}$ & $\begin{array}{l}50 \mathrm{IU} / \text { day } \\
100-400 \mathrm{IU} / \text { day }\end{array}$ \\
\hline \multirow[t]{2}{*}{ Vitamin $\mathbf{K}$} & Infants & & $0.3-1 \mathrm{mg} / \mathrm{day}$ \\
\hline & Older children & & $1-10 \mathrm{mg} /$ day \\
\hline
\end{tabular}

Table 3. The nutritional status goal in CF patient ${ }^{11}$

\begin{tabular}{|c|c|c|c|}
\hline Age & Measurement & Target & Evaluation \\
\hline $\begin{array}{l}\text { Infants ( } 0-2 \text { years }) \\
\text { Older children }(2-18 \\
\text { years })\end{array}$ & Weight-and-length & $\begin{array}{l}\geq 50^{\text {th }} \text { percentile of their age- } \\
\text { matched healthy population } \\
\geq 50^{\text {th }} \text { percentile of their age- } \\
\text { matched healthy population }\end{array}$ & $\begin{array}{l}\text { - Every } 1-2 \text { weeks if the } \\
\text { weight-and-length/BMI } \\
\text { do not reach } 50^{\text {th }} \\
\text { percentile } \\
\text { - Every } 1 \text { months in the } \\
\text { first year of life } \\
\text { Every } 3 \text { months }>1 \\
\text { years of life } \\
\end{array}$ \\
\hline \multicolumn{4}{|c|}{ Other Assessment } \\
\hline Children $8-10$ years & $\begin{array}{l}\text { Bone mineral density } \\
\text { (BMD) }\end{array}$ & $\begin{array}{l}\text { Matched with standard BMD z } \\
\text { score of same age and sex } \\
\text { healthy individuals }\end{array}$ & $\begin{array}{l}\text { Every } 1-5 \text { years depends on } \\
\text { the presence of risk factors } \\
\text { using DXA }\end{array}$ \\
\hline All age & Body composition & High lean body muscle mass & $\begin{array}{l}\text { Evaluation using BIA with } \\
\text { CF-specific equations, DXA, } \\
\text { air displacement } \\
\text { plethysmography, hand grip } \\
\text { strength, and double labelled } \\
\text { water measurement }\end{array}$ \\
\hline
\end{tabular}

Table 4. The recommended PERT dosages ${ }^{11}$

\begin{tabular}{|c|c|}
\hline Age & Dosage \\
\hline Infants ( $0-12$ months) & $\begin{array}{l}2000-4000 \mathrm{U} \text { lipase } / 120 \mathrm{~mL} \text { breastmilk or formula and } 2000 \mathrm{U} \text { lipase/gram of fat in diet if } \\
\text { infants already consume solids }\end{array}$ \\
\hline $\begin{array}{l}\text { Child ( } 1-4 \text { years }) \\
\text { Child }(>4 \text { years })\end{array}$ & $\begin{array}{l}\text { 2000-4000 U lipase/gram dietary fat with maximum dosage } 10.000 / \mathrm{u} \text { lipase } / \mathrm{kg} \text { per day } \\
\text { starting dose } 500 \mathrm{U} \text { lipase } / \mathrm{kg} / \mathrm{meal} \text { with maximal dosage } \\
\text { - } \quad 10.000 \mathrm{U} / \mathrm{lipase} / \mathrm{kg} \text { per day, or } \\
\text { - } \quad 1000-2500 \mathrm{U} \text { lipase } / \mathrm{kg} \text { per meal, or } \\
\text { - } \quad 2000-4000 \mathrm{U} \text { lipase } / \text { gram dietary fat }\end{array}$ \\
\hline
\end{tabular}




\section{Conflict of Interest}

Authors declared no conflict of interest regarding this article.

\section{Open Access}

This article is distributed under the terms of the Creative Commons Attribution 4.0 International Licence

(http://creativecommons.org/licenses/by/4.0/), which permits unrestricted use, distribution, and reproduction in any medium, provided you give appropriate credit to the original author(s) and the source, provide a link to the Creative Commons license, and indicate if changes were made.

\section{References}

1. Naehrig S, Chao CM, Naehrlich L. Cystic Fibrosis. Dtsch Arztebl Int. 2017;114:564-74.

2. Cutting GR EJ, Zeitlin PL. Genetics and pathophysiology of cystic fibrosis. In: Kendig's Disorders of the Respiratory Tract in Children. Elsevier. 2019:p. 757-68.

3. Park HW LM. Transepithelial bicarbonate secretion: lessons from the pancreas. Cold Spring Harb Perspect Med. 2012;2:1-7.

4. PB D. Cystic fibrosis since 1938. Am J Respir Crit Care Med. 2006;173(5):475-82.

5. Zolin A OA, Naehrlich L, Jung A, van Rens J et al. ECFS Patient Registry Denmark: European Cystic Fibrosis Society; 2018.

6. Li L SS. Digestive system dysfunction in cystic fibrosis: challenges for nutrition therapy. Dig Liver Dis. 2014;46(10):865-74.

7. Leung DH, Narkewicz MR. Cystic Fibrosis-related cirrhosis. J Cyst Fibros. 2017;16 Suppl 2:50-61.

8. Marshall B FA, Fink A, Loeffler D, Elbert A, O'Neil T et al. 2017 Patient Registry Annual Data Report. Bethesda, Maryland: Cystic Fibrosis Foundation; 2017.

9. Tridello G, Castellani C, Meneghelli I, Tamanini A, Assael BM. Early diagnosis from newborn screening maximises survival in severe cystic fibrosis. ERJ Open Res. 2018;4:1-5.

10. Sanders DB ZZ, Farrell PM, Lai HJ. Early life growth patterns persist for 12 years and impact pulmonary outcomes in cystic fibrosis. 2018;17(4):528-35.

11. Turck D, Braegger CP, Colombo C, Declercq D, Morton A, Pancheva R, et al. ESPEN-ESPGHANECFS guidelines on nutrition care for infants, children, and adults with cystic fibrosis. Clin Nutr. 2016;35:55777.

12. Charatsi AM DP, Freund R, Maruani G, Rossin H, Boulier A, et al. Bioelectrical impedance in young patients with cystic fibrosis: Validation of a specific equation and clinical relevance. J Cyst Fibros. 2016;15:825-33.

13. Declercq D, Van Meerhaeghe S, Marchand S, Van Braeckel E, van Daele S, De Baets F, et al. The nutritional status in CF: Being certain about the uncertainties. Clin Nutr ESPEN. 2019;29:15-21.

14. Calella P, Valerio G, Thomas M, McCabe H, Taylor J, Brodlie $\mathrm{M}$, et al. Association between body composition and pulmonary function in children and young people with cystic fibrosis. Nutrition. 2018;48:73-6.

15. Engelen MP, Com G, Deutz NE. Protein is an important but undervalued macronutrient in the nutritional care of patients with cystic fibrosis. Curr Opin Clin Nutr Metab Care. 2014;17:515-20.

16. Kaminski BA, Goldsweig BK, Sidhaye A, Blackman SM, Schindler T, Moran A. Cystic fibrosis related diabetes: Nutrition and growth considerations. J Cyst Fibros. 2019;18 Suppl 2:S32-S7.

17. Maqbool A G-MR, Schall JI, Zemel BS, Stallings VA. Vitamin A intake and elevated serum retinol levels in children and young adults with cystic fibrosis. J Cyst Fibros. 2008;7:137-41.

18. Singh VK, Schwarzenberg SJ. Pancreatic insufficiency in Cystic Fibrosis. J Cyst Fibros. 2017;16:70-8.

19. Brownell JN, Bashaw H, Stallings VA. Growth and Nutrition in Cystic Fibrosis. Semin Respir Crit Care Med. 2019;40(6):775-91.

20. Gelfond D, Heltshe SL, Skalland M, Heubi JE, Kloster M, Leung DH, et al. Pancreatic Enzyme Replacement Therapy Use in Infants With Cystic Fibrosis Diagnosed by Newborn Screening. J Pediatr Gastroenterol Nutr. 2018;66:657-63. 